\title{
Allochthonous and autochthonous components from gizzard grit of Theristicus melanopis in anthropogenic pastures of southern chile
}

\section{Componentes alóctonos y autóctonos en mollejas de Theristicus melanopis en praderas antropogénicas del Sur de Chile}

\author{
Alberto Gantz ${ }^{1 *}$, Carlos E. Valdivia ${ }^{1}$, Miguel Yañez ${ }^{2} \&$ Soraya Sade ${ }^{1}$ \\ ${ }^{1}$ Laboratorio de Ecología, Departamento de Ciencias Biológicas y Biodiversidad, Universidad de Los Lagos, Av. Fuchslocher \\ 1305, Osorno, Chile. \\ 2Departamento de Estadística, Facultad de Ciencias, Universidad del Bio-Bio, Concepción, Chile \\ *Email: agantz@ulagos.cl.
}

\begin{abstract}
Numerous vertebrates, and in particular birds, ingest stones (geo-gastrolites) to favour the breakdown and digestion of food in the muscular stomachs. Between 1993 and 1994 we evaluated the quantity, relative abundance and quality of autochthonous (geo-gastrolites) and allochthonous (pieces of glass) components of the grit in gizzards of black-faced ibis (Theristicus melanopis) inhabiting the pastures of southern Chile. Grit elements were present in 32 out of $48(66,7 \%)$ of all gizzard analysed. A total of 572 particles were recorded from which, $69.1 \%$ corresponded to autochthonous elements and $27.8 \%$ were allochthonous particles. Both components are similar in shape; however glass contributes considerably more in terms of mass. Gender differences reveal that females consume a significantly greater number of allochthonous elements than males. We postulate the hypothesis that, due to their high energy requirements, females ingest more pieces of glass to facilitate the breakdown and digestion of food with a limited nutritional value, thus increasing their reproductive success.
\end{abstract}

KeYwords: Black-faced ibis, glasses, gastrolites, pastures, south Chile

\section{RESUMEN}

Numerosos vertebrados y en particular las aves, ingieren piedras (gastrolitos) para favorecer la maceración y la digestión del alimento en los estómagos musculares. Entre 1993 y 1994 evaluamos la cantidad, abundancia relativa y calidad de componentes autóctonos (piedras) y alóctonos (trozos de vidrios) de los gastrolitos presentes en las mollejas de bandurrias (Theristicus melanopis) en praderas agrícolas del sur de Chile. Los gastrolitos se presentaron en 32 de las 48 (66,7\%) mollejas analizadas. Se registró un total de 572 partículas de las cuales $69,1 \%$ fueron elementos autóctonos y 27,8\% partículas alóctonas. Ambos componentes no difirieren en la forma pero los vidrios aportaron significativamente mayor masa. Las hembras consumieron un número significativamente mayor de elementos alóctonos que los machos. Postulamos la hipótesis que las hembras, con alto requerimiento energético, ingieren más trozos de vidrio para incrementar la eficiencia de maceración y digestión de alimentos con reducido valor nutricional, lo que les permitiría incrementar su éxito reproductivo.

Palabras clave: Bandurria, vidrios, gastrolitos, praderas agrícolas, sur de Chile

\section{INTRODUCTION}

Gastrolites are important components of avian consumption because they substantially contribute to grinding foods in the bird gizzard (Ziswiler \& Farner 1972, Wings 2007, Beaune et al. 2009) and, to a lesser extent, as a possible source of necessary minerals (Gionfrido \& Best 1996, Lee et al. 2004). Granivorous birds have been indicated as the main guild requiring gastrolites in their diets and, unsurprisingly, they have received much more attention than other guilds as insectivores (Gionfrido \& Best 1995, Lopez-Calleja et al. 2000). Grit consumption might also vary according to gender because females need a highly efficient ingestion of nutrients than males owing to dissimilar reproductive efforts; nevertheless, no empirical support has still been found on this regard (see Gionfrido \& Best 1996).

Grit consumption may be given by contrasting and exaggerated characteristics or particles (see Møller \& Erritzøe 2009) or, alternatively, by its efficiency in food 
grinding (Moore 1998, Amat \& Varo 2008). In this regard, the efficiency of grit is given by its quantity (e.g. number of gastrolites, total mass) and quality (e.g. shape, size), which may vary according to its origin and availability in the environment. Autochthonous grit is usually given by small-sized stones and shells and, for this reason, more easily to find than allochthonous components. By contrast, allochthonous grit may be given by a great number of particles left by human activities, and its abundance may vary according to the degree of disturbance of landscapes. The importance of allochthonous components has been highlighted in terms of its risk to animals. For instance, numerous birds consume inadvertently granular insecticides and/or $\mathrm{Pb}$ shot pellets from hunting activities, which may certainly provoke higher mortalities in pastures (Gionfrido \& Best 1995, 1996, Wings 2007, Martínez-Haro et al. 2011). Much less attention, however, has been put on noninjurious allochthonous particles consumed by birds. This is unfortunate because allochthonous components might be more efficient in grinding foods than autochthonous components, and may putatively contribute to enhance the overall fitness of birds.

The temperate rainforests of South America have suffered a long history of exploitation over the last century and, in some cases, more than $50 \%$ of its original surface has been logged for agriculture (Armesto et al. 2010). In these humandominated habitats numerous waste components (e.g. glasses from broken bottles) may be observed, but infrequently, particularly in the vicinity of roads. In these anthropogenic habitats thrives the black-faced ibis (Theristicus melanopis, Gmelin 1789) an endemic insectivorous bird from southern South America. The aims of this work is to evaluate the amount, relative abundance, and quality of autochthonous and allochthonous gastrolites consumed by black-faced ibis feeding in pastures at the disturbed temperate rainforest from southern South America. Regarding that sharp, bladelike particles (i.e. irregular shapes) are usually postulated to be more efficient in food grinding than regular particles (Moore 1998), we expect a higher amount of irregular rather than regular particles in bird gizzards. Given that allochthonous particles (e.g. broken glasses) might be sharper than autochthonous particles (e.g. stones), we expect a higher relative abundance of allochthonous rather than autochthonous components in bird consumption. Given that females need a more efficient nutrient ingestion than males, we expect a disproportionally higher relative abundance of sharper, allochthonous components of the grit of females.

\section{MATERIALS AND METHODS}

Study AREA

We conducted fieldwork in pastures covering an area of 57.5 ha located in a rural area of Chahuilco in the Lake District of southern Chile $\left(40^{\circ} 43^{\prime} \mathrm{S}, 73^{\circ} 10^{\prime} \mathrm{W}\right)$. The native vegetation corresponds to a temperate rainforest mainly given by the tree Nothofagus obliqua which, nonetheless, remains only as scattered individuals immerse in anthropogenic pastures. The numerous country roads in this area offer a high stone availability of an adequate size to be ingested by birds, and several types of wastes, although very scarce, may be found neighboring these roads, such as plastic fragments and broken glasses from bottles, among others.

\section{FIELD METHODS}

To evaluate the grit components of black-faced ibis, from autumn to spring of 1993 and 1994 but mainly in winter (reproductive period in this bird), we used the gizzard of 52 individuals (23 males, 25 females, one juvenile and three individuals with indeterminate sex) caught as part of a bigger project on feeding ecology of this bird species. All birds were killed with authorization of the Chilean authorities (Servicio Agrícola y Ganadero, SAG), in agreement with "reduction" concept of ethical normative, given by AVMA (2007; page $20)$ and the document "Use of animal in research" (2009) given by Bioethics Committee of Universidad Austral de Chile. We excluded from the analysis juveniles and birds with indeterminate sex because of reduced sample size. In males and females, we excised gizzards which were then dissected under laboratory conditions. From each gizzard, we severed and counted all of its content, which was classified according to its identity and origin (see Gantz 2010 for details). Thus, each particle was classified as autochthonous when was made by quartz $\left(\mathrm{SiO}_{2}\right)$ or allochthonous when was made by glass from bottles. Glass was confidently recognized from quartz because of its distinctive size, color and convex form. Further particles were also quantified and classified.

To assess the quality of grit in terms of its shape, we measured each particle from each individual corresponding to each category with a digital caliper (1-mm precision). Each particle was measured at its longer and shorter side to estimate the Shape Index (SI) according to Gionfriddo \& Best $(1995,1996)$. The SI was obtained as the longer side divided by the shorter side, and ranges from 1 (regular shapes) to $+\infty$ (irregular shapes) (Gionfriddo \& Best 1995, 1996). To evaluate the grit quality in terms of its mass, we put each particle into an oven at $90^{\circ} \mathrm{C}$ during $12 \mathrm{~h}$ to then obtain the dry mass of particles.

\section{STATISTICAL ANALYSIS}

We compare dry mass and SI of autochthonous and allochthonous particles in a particle-based procedure using Wilcoxon signed rank test. This test was used because it is useful when the data set comes from related samples (Siegel \& Castellán 1988). The amount of particles (dependent factor) per gender (independent factor 1) and per origin 
(independent factor 2) was compared using a 2x2 factorial Scheirer-Ray-Hare extension of Kruskall-Wallis test by using the type III error distribution in order to assess interacting effects. This non-parametric procedure was used because data set did not meet the normality assumptions required for the traditional 2x2 factorial ANOVA (see Sokal \& Rohlf 1994 for details).

\section{RESULTS}

In 32 out of the $48(66.7 \%)$ individuals of black-faced ibis we found grit components. Grit elements were present in $78.3 \%$ of the males and $56 \%$ of the females. Collectively, we found 572 particles mostly given by autochthonous (395 particles of stones, 69.1\%) rather than allochthonous particles (159 particles of glasses, $27.8 \%$ ). The remaining particles corresponded to autochthonous and allochthonous components: 13 seeds and 1 fragment of wires and plastic, respectively.

In terms of grit quality, the mean mass of glasses was two-fold higher than that of stones (Wilcoxon $Z=-2.154, P=0.031 ; N$ $=87$ ). The SI values did not differ between glasses and stones (Wilcoxon $Z=-1.763, P=0.078 ; N=45$ ) (Table 1).

In terms of grit consumption, the amount of particles consumed by birds depended on the origin of particles and the gender of birds, with females consuming more allochthonous (glasses) than males (Scheirer-Ray-Hare extension of Kruskall-Wallis test; Origin effect: $H=21.16$, $P<0.001, N=12$; Gender effects: $H=31.27, P<0.001$, $N=22$; Origin x Gender effects: $H=17.53, P<0.001, N$ $=20)$ (Fig. 1).

TABLE 1. Quality components (mass and shape) of gastrolites from the black-faced ibis feeding in pastures at Chahuilco, southern Chile. Values depict mean \pm 1 SE. Dissimilar letters depict significant differences $(P<0.05)$.

TABLA 1. Calidad de los components (masa y forma) de los gastrolitos de la bandurria que se alimentan en praderas agrícolas en Chahuilco, sur de Chile. Valores indican media \pm 1 ES. Letras diferentes indicant diferencias significativas.

Grit component

Autochthonous (Stones) Allochthonous (Glasses)

$\begin{array}{ccr}\text { Mass (g) } & 0.47 \pm 0.03^{\mathrm{a}} & 0.78 \pm 0.08^{\mathrm{b}} \\ \text { Shape (SI) } & 1.42 \pm 0.05 & 1.73 \pm 0.85\end{array}$

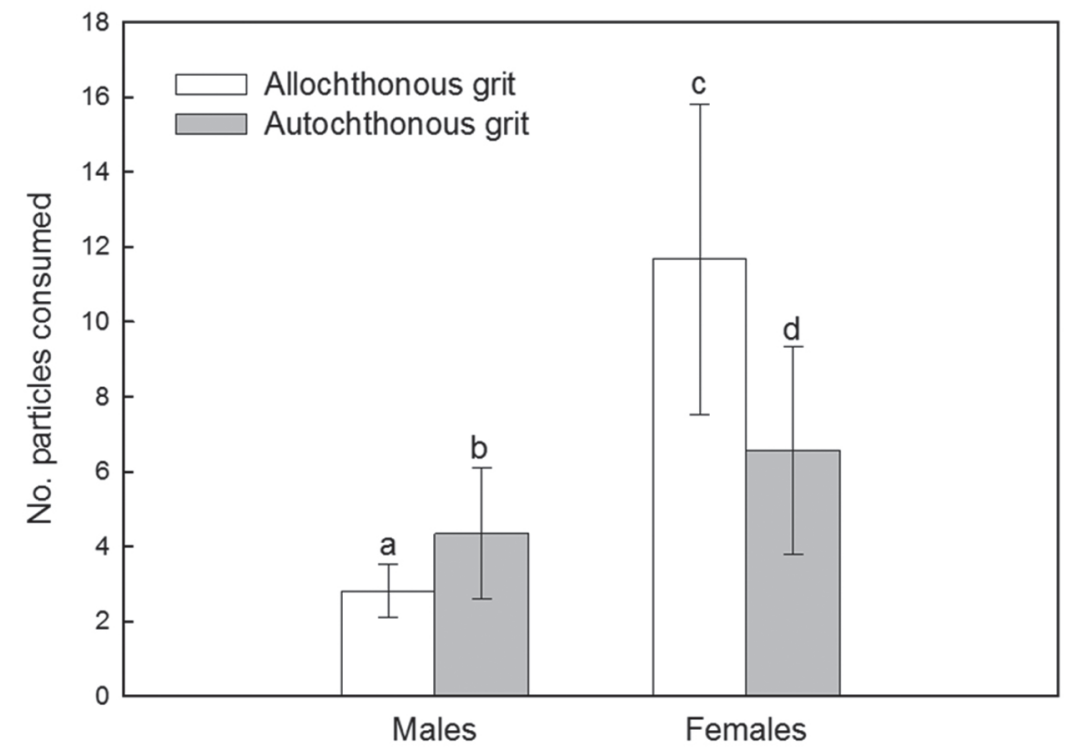

FIGURE 1. Amount of allochthonous and autochthonous particles consumed by males and females of the black-faced ibis at the pastures of Chahuilco, south Chile. Dissimilar letters depict significant differences. Means $\pm 1 \mathrm{SE}$ are depicted.

FIGURA 1. Cantidad de partículas alóctonas y autóctonas consumidas por machos y hembras de bandurria en praderas agrícolas de Chahuilco, sur de Chile. Letras diferentes indican diferencias significativas. Se indica la Media $\pm 1 E S$. 


\section{DISCUSSION}

Our results show highly frequent ingestion by black-faced ibis of autochthonous and allochthonous elements as grit components, and that this frequency is more accentuated in males than in females. Nevertheless, although the allochthonous elements were heavier, they were no more irregular than the autochthonous elements. The presence of autochthonous elements (geo-gastrolites, see definition in Wings 2007) in the gizzard of the black-faced ibis is in agree with the observations of various authors, who record geogastrolites, quartz and granite as the main components of grit in the gizzards of the majority of bird species, independent of the trophic guild to which they belong (Gionfrido \& Best 1995, 1996, López-Calleja et al. 2000, Wings 2007, Wings \& Sanders 2007).

Nevertheless, the presence of allochthonous elements in the gizzards of the black-faced ibis is intriguing. As far as we know, this is the first study to describe the presence of glass fragments as one of the grit components in the gizzard of insectivore birds. The likely causes leading to ingestion of allochthonous elements by black-faced ibis are not clear, as has also been reported previously in other species (Wings 2007). A possible explanation is that some structural traits of the grit particles as, for example brightness reflected by glasses, influence females preferences responses for this more attractive particle in correspondence with the sensorial bias model (see Basolo 1995, Borgia \& Keagy 2005, Fuller $\&$ Noa 2010). But, probably laminar planes of quartz particles also could generate bright reflex that birds could perceive, so this statements must be consider with caution and experimental studies must be developed to prove this hypothesis.

On the other hand, although our data do not provide conclusive results, and the data interpretation could be inserted in a speculative field, we postulate the alternative plausible hypothesis that the presence of allochthonous elements in the grit produces nutritional and energy advantages by facilitating the breakdown and digestion of food consumed by black-faced ibis. The texture of the allochthonous elements (glasses), with an abundance of sharp edges, similar to that of the autochthonous elements, but larger, probably reduces the time required to grind down large pieces of chitinized prey with low nutritional content, into smaller particles. Simultaneously, the smaller pieces and soft tissue of the food may undergo a second breakdown with the smooth surfaces of the smaller geo-gastrolites. The rapid destruction of large, hard pieces of prey due to the action of allochthonous elements would quickly expose the soft tissue (with greater nutritional content) to the action of gastric juices, favouring digestion and nutrient absorption per unit of time (Moore 1998). Similarly, it would enable the transit and retention time of food in the gizzard to be reduced (Gionfriddo \& Best 1996, López-Callejas et al. 2000, Prop et al. 2005, Amat \& Varo 2008). In turn, a shorter period of food retention allows greater consumption of food per feeding period, given that the volume of the gizzard limits the quantity of food that can be ingested (Amat et al. 1991, Moore 1998, Amat \& Varo 2008).

It is probable that greater food consumption provides nutritional benefits for black-faced ibis during periods of high energy demand and when high quality preys are scarce. In fact, in southern hemisphere, during winter, at the beginning of reproductive period, black-faced ibis concentrate their feeding activity on high quality hypogeous insect larvae which are more abundant and available in the pastures. But in spring-summer period, at the end of their breeding period, when insect larvae are unavailable, black-faced ibis switch their diet to adult insect (mainly beetles) more abundant (Gantz \& Schlatter 1995) but with low energetic quality. In this context, in southern Chile the spring-summer period could impose critical nutritional limitations on populations of this bird. This limitation could arise by the combined effect of reduced availability and nutritional value of adult insects, together with a high energy demand during the breeding season and chick-feeding period, and potentially could negatively affect the reproductive success of females. For example, in extreme climatic conditions (drought), numerous landowners have reported considerable mortalities in black-faced ibis juveniles due to starvation. This suggests that when environmental conditions are critical, juveniles do not have access to quality food in sufficient quantities for their sustenance, or that the quality of food provided by the females is insufficient or inadequate. In this respect, many authors have shown that reduced availability of low nutritional quality food significantly and negatively affects the size of the clutch and brood survival, and so, the reproductive success of numerous bird species (Martin 1987, Brickle et al. 2000, Martin et al. 2000, Newton 2004, Neigh et al. 2007, Reif et al. 2008). In this regard, if the allochthonous elements really do increase food consumption and digestive efficiency, they could supplement, at least up to a certain critical level, the poor nutritional and energy quality of prey available during periods of nutritional limitation. This would provide an explanation as to why black-faced ibis females, with higher energy requirements, consume significantly greater numbers of allochthonous elements than the males. If this were the case, it is probable that ingestion of allochthonous elements by females would enable them to supply their offspring with sufficient nutrients to guarantee their survival and maintain the female reproductive success of black-faced ibis throughout critical nutritional periods in the study area.

Undoubtedly, additional studies are required to further 
clarify the functional role of allochthonous elements and to verify whether their consumption provides any nutritional advantage that favours the reproductive success of blackfaced ibis in these man-dominated habitats.

\section{ACKNOWLEDGEMENTS}

The authors want to thanks to Mr. Osvaldo Dimter for authorize the acces to their farm. To Dirección de Investigación de La Universidad de Los Lagos for finantial support for this study.

\section{BIBLIOGRAPHY}

Amat, J. A., \& VAro, N. 2008. Grit ingestion and size-related consumption of tubers by Graylag Geese. Waterbirds 31: 133-137.

amat, J.A., García-Criado, B. \& García-Ciudad, A. 1991. Food, feeding behaviour and nutritional ecology of wintering grey geese Anser anser. Ardea 79: 271-282.

Armesto, J. J., Manuschevich, D., Mora, A., Smith-Ramirez, C., Rozzi, R., Abarzúa, A. M. \& Marquet, P. A. 2010. From the Holocene to the Anthropocene: A historical framework for land cover change in southwestern South America in the past 15,000 years. Land Use Policy 27: 148-160.

aVma (American Veterinary Medical Association). 2007. AVMA Guidelines on Euthanasia. On-line version: www.avma. org/KB/Policies/Documents/euthanasia.pdf

Beaune, D., Le Bohec, C., Lucas, F., Gauthier-Clerc, M. \& Le Мано, Y. 2009. Stomach stones in king penguin chicks. Polar Biology 32: 593-597.

Brickle, N. W., Harper, D. G. C., Aebischer, N.J. \& Cockayne, S.H. 2000. Effects of agricultural intensification on the breeding success of corn buntings Milandria calandra. Journal of Applied Ecology 37: 742-755.

Gantz, A. \& R. Schlatter. 1995. La dieta de la bandurria (Theristicus caudatus melanopis Gmelin, 1789) en praderas agrícolas del sur de Chile. Medio Ambiente 12: 35-38.

GANTZ, A. 2010. Winter food preference of Black-faced Ibis (Theristicus melanopis, Gmelin 1789) in pastures of southern Chile. Ornitología Neotropical 21: 241-250.

Gionfriddo, J. P., \& Best, L. B. 1995. Grit use by house sparrows: effects of diet and grit size. The Condor 97: 57-67.

Gionfriddo, J.P. \& Best, L. B. 1996. Grit use patterns in North American birds: the influence of diet, body size and gender. The Wilson Bulletin 108: 685-696.

Lee, D. E., Hamman, M.G. \& Black, J.M. 2004. Grit-site selection of black brant: particle size or calcium content? The Wilson Bulletin 116: 304-313.
López-Callejas, M. V., Soto-Gamboa, M. \& Rezende, E.L. 2000. The role of gastrolites on feeding behavior and digestive efficiency in the Rufous-Collared Sparrow. The Condor 102: 465-469.

Martin, Th. E., Martin, P.R., Olson, C.R., Heidinger, B.J. \& Fontaine, J.J. 2000. Parental care and clutch sizes in North and South American birds. Science 287:1482-1485.

Martin, Th.E. 1987. Food as a limit on breeding birds: a lifehistory perspective. Annual Review of Ecology and Systematics 18: 453-458.

Martínez-Haro, M., Green, A.J., Acevedo, P. \& Mateo, R. 2011. Use of grit supplements in waterbirds: an experimental assessment of strategies to reduce lead poisoning. European Journal of Wildlife Research 57: 475-484.

Møller, A. P., \& Erritzøe, J. 2009. Why birds eat colourful grit: colour preferences revealed by the colour of gizzard stones. Journal of Evolutionary Biology 23: 509-517. doi:10.1111/j.1420-9101.2009.01918.x.

Moore, S. J. 1998. Use of an artificial gizzard to investigate the effect of grit on the breakdawn of grass. Journal of Zoology, London 246: 119-124.

Neigh, A. M., Zwiernik, M.J., Joldersma, C.A., Blankenship, A.L., Strause, K.D., Millsap, S.D., Newsted, J.L. \& Giesy, J.P. 2007. Reproductive success of passerines exponed to polychlorinated biphenyls through the terrestrial food web of the Kalamazoo River. Ecotoxicology and Environmental Safety 66: 107-118.

Newton, I. 2004. The recent declines of farmland bird populations in Britain: an appraisal of causal factors and conservation actions. Ibis 146: 579-600.

Prop, J., Van Marken Lichtembelt, D., Beekman, J.H. \& Faber, J.F. 2005. Using food quality and retention time to predict digestion efficiency in geese. Wildlife Biology 11: 21-29.

Reif, J., Vořišek, P., ŜŤatsný, K., BejĈEK, B. \& Petr, J. 2008. Agricultural intensification and farmland birds: new insights from a central European country. Ibis 150: 596605.

Siegel, S. \& N.J. Castellan. 1988. Nonparametric statistics for the behavioral science. $2^{\text {nd }}$ ed. McGraw.Hill, Singapore.

SoKal, R. R., \& RohlF, F.J. 1995. Biometry. $3^{\text {rd }}$ ed. Freeman and Co., San Francisco, USA.

WINGS, O. 2007. A review of gastrolith function with implications for fossil vertebrates and a revised classification. Acta Paleontologica Polonica 52: 1-16.

Wings, O., \& SAnders, P.M. 2007. No gastric mill in sauropod dinosaurs: new evidence from analysis of gastrolith mass and function in ostriches. Proceeding of the Royal Society, London, B 274: 635-640.

Ziswiler, V., \& Farner, D.S. 1972. Digestion and the digestive system. In: Avian Biology. (Eds. Farner D.S., \& King, J.R.), pp: 343-430. Vol. III. N ${ }^{o}$. Book Press, New York, USA.

Recibido: 11.06.12

Aceptado: 26.10 .12 